\title{
Muhammadan Educational Conference: It's Impact on the Development of Modern Education for Muslim Community in Rajasthan During $20^{\text {th }}$ Century
}

\author{
Gulshan Zubair \\ Aligarh Muslim University, Aligarh.U.P (India)
}

\begin{abstract}
The Muhammadan Educational Conference established by Sir Syed Ahmad khan on $27^{\text {th }}$ December 1886, in stretchy hall of the Aligarh College, presided over by Maulvi Samiullah Khan, the co-founder and a trustee of the college. It was an advance guard of his educational movement promoting modern, liberal education for the Muslim community in India. Its annual meetings were held in different parts of the country where by the co-operation of the local Muslims, the conference succeeded holding its sessions in every nook and corner of the country like- Utter Pradesh, Maharashtra, Delhi, Punjab, West Bengal, Tamil Nadu, Haryana, Madhya Pradesh, Rajasthan (Ajmer), Bangladesh, and Burma etc. steps were taken for the progress of education and its platform became the forum for the creating of new literary trends and new educational ideals.

The role of Aligarh Movement is incredible for the progress of Muslim education in Indian subcontinent during $20^{\text {th }}$ century. The impact of Aligarh Movement also felt extensively in the province of Ajmer and Merwara. It is important to note that for the first time the All India Muslim Educational Conference's annual meeting held under the president ship of Sir Shah Sulaiman after gap of 42 years at Ajmer. This session of the Conference is significant in the history of Muslim edification of Rajasthan region since it powerfully promulgated the idea of providing modern, vocational and religious education. It passed significant resolutions not only for the Muslim males but also to the Muslim female development of modern and traditional education. Various resolutions of Ajmer session sought the attention of British Government as well as princely states of Rajputana and princely state of Tonk towards the prevalent dreadful circumstances of Muslim education in $20^{\text {th }}$ century.
\end{abstract}

In the middle of the 19th century Modern education, according to Lord Macaulay's Minute on Education, came into sight to have started in Rajasthan. Efforts to introduce modern education in AjmerMerwara area began in 1819. English medium schools were first introduced in Alwar and Bharatpur in 1842, in 1844 in Jaipur and in 1863 in Udaipur. The provision of education was different among princely states depending upon the direction of the rulers and the ease of use of economic income. Jaipur was at the front position of modern education in Rajasthan where in 1844 the Department of Public Instruction had been recognized. Under the patronage of the Maharaja Sawai Ram Singh Bahadur, a Sanskrit college for boys and a school for girls were opened. . And the lack of girls' school was common in all the state. The education scenario in smaller states, e.g. Banswara, Dholpur, Bundi, Shahpura, Pratapgarh and Dungarpur, was very changed. For example, In Bundi and Bikaner, schools were inadequate to Persian/Sanskrit schools and pathshalas/Chatshalas in that order. The restricted number of girls' schools that established under the patronage of the Maharaja in Jaipur by 1867, like- Jaipur Central Girls School. In general, girls' education was considered unimportant and suffered from traditional social attitudes and traditions, as well as from a lack of (Ustanis) the female teachers. Even by the 1930s, the situation was not much better, with girl's schools accounting for just about only 10 percent of the total numeral of schools in Jaipur state.

Muslim Educational Conference was concerned primarily with Muslim education. It kept a vigilant eye on the spread of modern education among Muslims and passed resolution and took steps to deal with the factors which were hindering its progress. It became a platform for Indian Muslim intelligentsia to mobilize Indian Muslim masses to promote education and specially modern and western education. They can clear there doubt and misconceptions about western and modern education. The conferences were much more than a gathering of Muslim educationist. It gave an opportunity to Aligarh Movement leaders to support it. Sir Syed thought that only college could not serve the educational need of the Indian Muslims. He considered it necessary to organize a movement and create a necessary atmosphere for the extended educational activities.

Thus in 1886 he envisaged the formation of a body named it all India Muhammadan educational congress. Since the word "congress" confused the people with that of the Indian national congress already been founded a year ago, it was dropped in 1890 and the body came to be known as All India Muhammadan Educational Conference. In 1895 "Anglo oriental was further added in it and it came to be known as All India Muhammadan Educational Conference. In it $36^{\text {th }}$ meeting held at Aligarh in 1923 which was chaired by sahib 
Zada Aftab Ahmad Khan, Muhammadan was replaced by Muslim and the body came to be known as The All India Muslim Anglo Oriental Conference.

The life of All India Muslim Educational Conference can be broadly divided into five phases or period (these phases were described by Abdul Rashid khan);

1886-1898

1898-1907

$1907-1917$

$1917-1945$

1947-till date
Sir Syed Ahmad Khan's period.

Muhsin-ul Mulk's period.

Sahibzada Aftab Ahmad khan's period.

Navab Sadar Yar Jang's period.

post independence period.

\section{Aims and objectives of the Conference}

The following are the aims and objectives of the conference

A- To spread among the Muslims European sciences and literature and promoting it to a very high level and endeavouring to educate Muslim to the highest of level in these disciplines, and to think out the plans towards this.

B- To find out the condition of Indian instructions in the English schools established by the Muslims, for the Muslim education, and to promote such instructions in the best possible way.

C- To find out the condition of maktabs for the teaching of the letter of Quranic text to the children of the common people and learning the whole Quran by heart, in vogue among them, now on the wane, and to adopt the measure for the preservation of and strengthening of the same.

D- Those receiving instruction in oriental disciplines and theology from the Ulema of our committee, and they having laid it down as their aim to find out their condition and to adopt all possible appropriate measures for the continuance of such instructions.

The measures to be adopted for the promotion of the aims and objectives of the conference;

1- Muslim population of the district and town based on the last census.

2- Number of government schools, mission schools and the number of Muslims in it.

3- Number of Madarsa and primary schools along with the Ulema giving education therein.

4- Number of government mission girls schools, and number of Muslim girls in it.

5- Number of Anjumans doing welfare service to the district.

6- Family background, financial status and general condition of the Musalmans of that district.

\section{All India Muhammadan educational conference} In Ajmer (Rajasthan), 1928

With the passage of time the congress had its session almost all provinces of India. Ajmer occupies a unique position as a place of Muslim pilgrimage in India, the sacred shrine of great Khawaja Moinuddin Chishti has been a centre of attraction for seven centuries, through which thousands of Muslim have year after came to pay homage to the famous saint buried in the mausoleum. It is in the fitness of things that all India Muslim educational conference should hold its session at this palace where large numbers of Musalmans congregate every year. The reception committee is to be congratulated on inviting the conference to Ajmer, and thereby giving a new encouragement to the educational movement in this part of the country.

The forth one Muslim educational conference held at Ajmer, December 26-29, 1928 which was presided over by Sir Shah Mohammad Samiulla khan born on 1886 at Jaunpur. And Navab Sadr Yar Jang Habeeb-ur Rahman khan Sherwani was the Hony Secretary of the period (1917-1945). There were many eminent people who attended this session at Ajmer but there are some speakers who presented their resolution; Mirza Mohammad Hasan Sahib (prof. of Dhaka university) on the topic- protection of Muslim Educational rights, Maulvi Syed Abdul Jabbar Sahib on the topic-vicegerency of Muslims in Educational committee, competitive examination, hygiene and sanitation, Mirza Abdul Qadir Sahib on the topic-Development of madarsa education, Muslim education in majority status, free primary education should be compulsory, establishment of Central Library, demand of two lack rupees for women's education, appointment of Muslims in railway workshop, demand for the development of education in Tonk, renewal of the oriental college of Jaipur, financial appeal for the Muslim institutions, appeal to the maharaja of Alore for the theology and the Quranic education in private schools, appointment of Muslims in training schools, appeal for Persian education in intermediate college of Udaipur and optional Arabic education should be in Ajmer Mewar, Mr. Shams-ul Ghani sahib on the topic- women's education, Aziz Ahmad Zubairi on the topic-appeal for educational boarding's, and progress of Islaimia School Ajmer to intermediate college etc. Some of the important resolutions which was passed in the conference for the promotion of Muslims education in Rajasthan state, are as follows: 
Professional education: concentration was given on the need of professional education in Madarsas and Conference's delegates' elevated voice to introduce professional education in Madarsas. Besides it, request was also prepared to initiate separate schools for professional education where provision of education of small scale trade and handicrafts should be complete.

Proposal for the establishment of Central Library: proposal was mooted out to the establishment a Central Library For the posterity of Urdu language and its development. In this favor following resolution was passed.

"This Conference believes it essential to establish a Central Library for the safeguarding of Urdu books, translated or compiled on different subjects so that development of Urdu language and its posterity could be arranged, since the infrastructures are accessible at Aligarh Muslim University, Aligarh. Even adequate staffs are also present there; therefore the Central Library must be established in the premises of Aligarh Muslim University. Muslim writers, authors and outstanding characters are demanded to donate their written works in Urdu language to the anticipated library."

Military Education: Conference's concentration was also concerned over the question of military education and it requested to the Government that it should make available military education to Muslims in its schools It also requested that representation should be given to Muslims in centrally directed Educational boards at Block level.

Fortification of Educational Rights of Muslims: there was some proposal according to the Muslim educational conference and ways which required from the British government to shelter the educational privileges of the Muslims.

a. Muslim students should have a share in the Government scholarship, which is given for foreign studies.

b. There should be made a Muslim representation in the Committee of Government Education Inspectors.

c. Muslim Representatives should be agreed in educational Institutes of the Government.

d. Satisfactory posts should be appointed for Muslim students in Academic Institutes of the Government.

e. Muslim Representatives should be appointed in governing bodies and associations of Universities and in the educational Boards of Secondary Education.

Arrangement of Quranic studies and Urdu teaching should be made to provide in the Government school.

Female Education: spotlight was also given on the requirements of the female education in the country. In this regard, following suggestions were given by the Muslim educational conference.

a. The national curriculum of the female education should be given according to the requirements of the society.

b. There is duty of the government that it should provide qualified women teachers to the Girls Schools.

The medium of language for the Girls at the level of primary and secondary education should not be English and constantly it should not be made obligatory subject matter of the national curriculum at this height.

Requirement of Inspectors for Moinia Islamia School: by the conference an appeal was made from the regional administration of Ajmer and Merwara to assign inspectors for Moinia School who should be under the direction of the Department of Education, the utmost right and they also should have the power to grant funds for the development of the Moinia School of Ajmer.

Need of an Educational Board of Control: Resolution was passed to establish an Educational Board of Control in the province of Ajmer and Merwara wherein representation of Muslims should be given.

Progression of Moinia High School to Intermediate level: Demand was made to convert it into intermediate level, taking into consideration the educational importance of Moinia School for the Muslims, seeing as it had served its services to the Muslims from its beginning. Subsequent proposals were put forwarded in the conference for its regards:

a. Teaching of Quranic/Arabic should be given unique concentration in the core syllabus.

b. Arrangement should be made for the education of commerce and other vocational subjects of utility.

c. Collection of useful instruction manual training of different works should be making available there.

d. A Boarding House should be constructing in the proposed for the Intermediate Moinia School therefore the students who would be receiving education could live there contentedly.

e. The supervision of proposed Intermediate Moinia School should be beneath a brilliant Head Master who would have capable Muslim staffs under him

Grants for Female Education: A scheme of two lakh rupees was made for the establishment of a Girls School in the state of Ajmer and Merwara. At the result following resolution was passed:

"Considering the present condition of the status of Muslim female education, and its increasing necessity in the region of Ajmer and Merwara province, Conference feels it necessary to establish a full-fledged Government 
College. It also sought the attention of the British Government and the provincial government and the princely government to provide some financial grants for the same."

Muslim Education in the Princely state of Rajputana: there were also some Steps which were taken to draw the concentration of the Hindu Princely States of Rajputana for the upliftment of educational condition of Muslims. In this regard, some steps were discussed in the Conference's meeting which are as follow:

a. Urdu should be sponsored in different academic institutions and Urdu language should be given the place of second language in the official purpose.

b. Request was made to the Hindu rulers that sufficient money should be spent on the education of Muslims in the princely states of Rajputana.

c. Proposal for the recruitments of Muslims in the local workshop of Railway as an apprentice was made in the course of the Conference's platform. It was also resolved that suitable technical training should be imparted for the same to the Muslims.

Muslim Education in the Princely State of Tonk: In the Muslim Princely state of Tonk, efforts were made to bring excellence in Muslim education. For this purpose some resolutions were passed and following suggestions were given to get better the condition of Muslim education.

a. Proper arrangement should be made for the education of Muslim education. Spending of money on Muslim education should be increased to $10 \%$.

b. Qualified instructor should be allotted in the different high schools of the princely state of Tonk.

c. Anglo-Vernacular schools should be established in different parganas of Tonk.

\section{Conclusion}

In assessing the role of Muslim Educational Conference as an effective representative organization in Rajasthan in 1928 the Conference asked to the ruler of the central state to provide resource for education of Muslim according to the proportion of their population. It is also asked the government of Alwar to make adequate arrangements for the teaching of Arabic Persian and Urdu. In Ajmer Mewar the inclusion of Arabic as a second language and as optional subject was also demanded. While Alwar and Bharatpur states were requested to make facilities available to the neo-Muslims, of whom there were more than two lacks, the conference itself opened some Maktabs; requests were made to raise the status of Mueena Islaimia School, Ajmer $^{21}$ and opening of a department of Islamic history and culture at Jaipur University. ${ }^{22}$

During the period 1927-1939 the All India Muslim Educational Conference published 78 books. The following are the published books of 1928 :

1-Islah-e Tamaddun:

2-salatin-e Maa'bar:

2-Khutbat-e Aliya;

3-Risala-e Taleem-o Taraqqi justice Dr., sir shah Suleman (Aligarh 1928)

Hakeem Syed Shamsullah Qadir (Aligarh 1928)

Anwar Ahmad Zubairi (Aligarh 1927-28) in 3 volume.

(editors) Dr. Abid Husain

Dr. S. Zafar-ul Hasan

Khawaja Ghulam-us Saqlain.

[1]. Report Muhammadan Educational Conference, 1886, p.1

\section{References}

[2]. Abdul Rashid khan, the all India Muslim educational conference its contribution to the cultural development of Indian Muslims 1886-1947, oxford university press,2001,p.22

[3]. Report MEC 1886, p.1

[4]. Shan Muhammad, the all India Muslim educational conference, new delhi,2003, p.1

[5]. Abdul Rashid khan, op.cit,p.12

[6]. Report of M.E.C,1886,p.1

[7]. Ibid,1903,p.1

[8]. Ibid,1892,p.1

[9]. Ibid,1908,p.1

[10]. Ibid,1899,p.1

[11]. Ibid,1901,p.1

[12]. Ibid,1931,p.1

[13]. Ibid,1918,p.1

[14]. Ibid, 1928,p.1

[15]. Ibid,1906,p.1

[16]. Ibid,1909,p.1

[17]. Abdul Rashid khan, Ibid. p.x

[18]. B.N. Dhoundeyal, District Gazetteer, Ajmer, Sharma Brother Electrometric Press, Alwar (Raj.)1966,p.1

[19]. Panjah Salah Tarikh, pp 258-269

[20]. G.S. Verma (1986), "History of Education in Rajasthan", pp. 37. Sabd Mahima, Jaipur.

[21]. Ibid, p.53.

[22]. Report of MEC,1886, pp.2,3

[23]. Shan Muhammad,op.cit,pp.xii,xiii

[24]. K.A.Nizami, Sir Syed centenary paper, a commemoration of the 100 years death anniversary of Sir Syed 
[25]. Ahmad Khan, March 1990, pp.12, 13.

[26]. Akhtar-ul Wasey ,Education of Indian Muslims; a study of all India Muslim educational conference 1886-1947, new Delhi 1977, p. 24

[27]. Ibid, pp.24-25.

[28]. Abdul Rashid khan, op.cit, p.22.

[29]. Shan Muhammad, Op.cit, p. xv.

[30]. Panjah Salah Tarikh,Ibid, p.259

[31]. Gazetteer of India Rajasthan, Ajmer Alwar press, Rajasthan, March 1966, p.444.

[32]. Shan Muhammad, op.cit,p.444

[33]. Panjah Salah Tarikh p.259.

[34]. Ibid. p.258.

[35]. Akhtar-ul Wasey, 1977.p.55.

[36]. Panjah Salah Tarikh, Ibid, pp.258-269.

[37]. Resolution No.19. P.264. Above Resolution No. 7 was proposed by Prof. Shamshul Ghani, TrainingCollege, and seconded by Raza Hussain Khan. See for details,

[38]. Above Resolution was proposed by Mirza Abdul Qadir Beg and seconded by Moulvi Mohiuddin

[39]. See Resolution No.19, p.269. Ibid.

[40]. See Resolution No.2, Ibid.

[41]. See Resolution No.3, Ibid

[42]. Panjah Salah Tarikh, Ajmer Session, 1928,pp.259-60

[43]. See Resolution No. 7, Ibid.

[44]. See Resolution No.20. Ibid.

[45]. See Resolution No. 22.Ibid.

[46]. See Resolution No, 23. Ibid.

[47]. See Resolution No, 24. Ibid

[48]. See Resolution No, 26.

[49]. Ibid Resolution no.6 moved by Viqar-ul Mulk and indorsed by dr. Zia-ud din Ahmad, Marharwi, Muraqqa, p.65,66

[50]. Ibid, p.268

[51]. Report of primary education committee 1929-1930, (Calcutta 1930) p.65-66

[52]. Abdul Rashid Khan, op.cit, p.237

[53]. Report M.E.C 1944, p. 50.

[54]. Akhtarul Wasey, op.cit, pp.87,88 